\title{
Immunologic aspects of characteristics, diagnosis, and treatment of coronavirus disease 2019 (COVID-19)
}

Feng-Yee Chang ${ }^{1}$, Hsiang-Cheng Chen², Pei-Jer Chen ${ }^{3}$, Mei-Shang Ho ${ }^{4}$, Shie-Liang Hsieh', Jung-Chung Lin ${ }^{1}$, Fu-Tong Liu ${ }^{4^{*}}$ (D) and Huey-Kang Sytwu ${ }^{6}$

\begin{abstract}
On March 11, 2020, the World Health Organization declared the worldwide spread of the infectious disease COVID19, caused by a new strain of coronavirus, SARS-CoV-2, as a pandemic. Like in all other infectious diseases, the host immune system plays a key role in our defense against SARS-CoV-2 infection. However, viruses are able to evade the immune attack and proliferate and, in susceptible individuals, cause severe inflammatory response known as cytokine storm, particularly in the lungs. The advancement in our understanding of the mechanisms underlying the host immune responses promises to facilitate the development of approaches for prevention or treatment of diseases. Components of immune system, such as antibodies, can also be used to develop sensitive and specific diagnostic methods as well as novel therapeutic agents. In this review, we summarize our knowledge about how the host mounts immune responses to infection by SARS-CoV-2. We also describe the diagnostic methods being used for COVID-19 identification and summarize the current status of various therapeutic strategies, including vaccination, being considered for treatment of the disease.
\end{abstract}

Keywords: COVID-19, SARS-CoV, SARS-CoV-2, Adaptive immunity, Innate immunity, Antibody-dependent enhancement, Cytokine storm, Vaccine

\section{Introduction}

On December 31, 2019, a cluster of cases of pneumonia was announced in Wuhan, Hubei Province, China. Subsequently, on January 7, 2020, the Chinese health authorities confirmed that this cluster was associated with a novel coronavirus, $\mathrm{nCoV}$, which was later named as SARS-CoV2 , and the ensuing disease was named COVID-19. The COVID-19 outbreak by the new coronavirus strain was recognized as a pandemic by the World Health

\footnotetext{
* Correspondence: ftliu@ibms.sinica.edu.tw

This review was prepared on behalf of Chinese Society of Immunology, located in Taiwan, and is dedicated to the International Day of Immunology (April 29, 2020), designated by the International Union of Immunological Societies (IUIS).

${ }_{4}^{4}$ Institute of Biomedical Sciences, Academia Sinica, 128 Academia Road, Section 2, Taipei, Taiwan

Full list of author information is available at the end of the article
}

Organization (WHO) on March 11, 2020. Throughout history, there have been a number of pandemic diseases; the more notable and recent ones caused by viruses include the influenza pandemic (Spanish flu) in 1918 and another by the influenza virus H1N1 in 2009.

The immune system clearly plays a key role in the host defense against the infectious agents during these pandemics. The host is able to mount immune responses upon infection by viruses, as well as other microbes, and control the spread of these pathogens within the body. However, some viral strains are capable of evading the immune attack and proliferate in the body, as well as elicit inflammatory responses, in particular in the lungs, resulting in pneumonia. More importantly, in susceptible individuals, viruses can cause massive inflammatory responses, known as "cytokine storm", resulting in a severe 
pathological consequence. The advancement in our understanding of the mechanisms of the host immune response are crucial to development of approaches for prevention and treatment of these fast spreading and devastating infectious diseases. The components derived from our immune systems, such as antibodies, can be used to develop sensitive and specific methods for the diagnosis of infectious diseases, as well as novel therapeutic modalities.

In this review, we briefly summarize our knowledge about the host immune response upon infection by SARS-CoV-2. We also discuss the epidemiological aspects of the outbreak, and the potential mechanism of the severe host response, such as cytokine storm. We also describe the antibody-based approaches for diagnosis of COVID-19 infection and summarize the current status of various preventive and therapeutic modalities for treatment of the infection.

\section{Epidemiology}

Coronaviruses are single-stranded enveloped RNA viruses that cause diseases in mammals and birds. In humans, the low pathogenicity strains, including $\mathrm{HCoV}$ 229E, HCoV-OC43, HCoV-NL63, and HCoV-HKU, infect the upper respiratory tract and cause mild to moderate common cold-like symptoms in healthy individuals. They are responsible for $15-30 \%$ of all common cold cases. The highly pathogenic strains, including those causing severe acute respiratory syndrome [SARS$\mathrm{CoV}]$, Middle East respiratory syndrome [MERS-CoV], and COVID-19 [new SARS-CoV-2], infect the lower respiratory tract and can cause severe pneumonia [1].

In addition to their RNA genetic material, coronaviruses are composed of nucleocapsid $(\mathrm{N})$ and spike $(\mathrm{S})$ proteins, which participate in viral genome assembly, transcription and replication, or mediate viral entry and cause cytopathic effect $[2,3]$. The $S$ protein mediates the fusion of viral and host membrane [4] and contains a receptor-binding domain (RBD) that attaches to cells during viral entry. Angiotensin-converting enzyme 2 (ACE-2) is the receptor for both SARS-CoV and SARSCoV-2 [5]. Notably, the four human coronaviruses that cause common cold like symptoms show limited sequence homology in their $\mathrm{N}(30-67 \%)$ and $\mathrm{S}$ proteins (9-57\%) compared with those of SARS-CoV-2 [6]. MERS-CoV also exhibits more distal relationship to SARS-CoV and SARS-CoV-2. However, the latter two are more closely related, with their $\mathrm{N}$ and $\mathrm{S}$ proteins sharing high homology (70-90\%).

In 2003, the SARS-CoV infection, which started in southern China, led to an epidemic; in total, over 8400 cases were reported, which included close to 900 deaths with a case fatality rate of $11 \%$ [7]. In 2012, the first case of MERS took place in Saudi Arabia. From that moment on, close to 2500 cases have been reported globally, which included close to 860 deaths, with an estimated case fatality rate of approximately $34 \%$ [8].

Evidence is mounting that COVID-19 spreads via human-to-human transmission of the virus [9]. After exposure to SARS-CoV-2, the majority of patients recover with little or mild symptoms that include cough and fever [10]. However, it is estimated that approximately $20 \%$ of infected individuals develop severe disease, including acute respiratory distress syndrome (ARDS). According to WHO, as of April 22, 2020, a total of 2,503, 072 confirmed cases of COVID-19 have been detected and 171,791 deaths resulting from the infection have been confirmed worldwide. The case fatality rates in Wuhan and worldwide were approximately 4.5 and $6.9 \%$, respectively. The numbers are lower in some countries, for example approximately $5.4 \%$ in the United States, $2.2 \%$ in South Korea, 3.3\% in Germany, and $1.4 \%$ in Taiwan. These numbers are likely affected by the extent of screening, thereby implying that COVID-19 cases might be underdiagnosed in many other countries. The availability and infrastructure of medical facilities in afflicted countries, especially those seriously affected ones, also likely affect the overall death rates.

Using public and published information, Wu et al. estimated that the overall "symptomatic case fatality risk" (the probability of dying after developing symptoms) associated with COVID-19 was $1.4 \%$ [11]. The rate of development of severe symptoms and death are clearly associated with the age. It is to be noted this is based on all tested and confirmed cases of COVID19, and the true fatality risk is likely lower than $1.4 \%$, since many mildly symptomatic/asymptomatic people might have never got tested. Nevertheless, the risk is still higher than that associated with seasonal influenza virus, which is approximately $0.1 \%$.

With regard to the spectrum of the severity of the disease, Chinese Center for Disease Control and Prevention reported of the 44,672 confirmed cases (with the age distribution of $\geq 80$ years: $3 \%$; $30-79$ years: $87 \%$; $20-29$ years: $8 \% ; 10-19$ years: $1 \%$; < 10 years: $1 \%)$, the spectrum of disease were: mild: $81 \%$; severe: $14 \%$, critical: $5 \%$; and case fatality rate: $2.3 \%$ [12]. Finally, the basic reproduction number (Ro) of the virus has been estimated to be between 1.4 and 3.9, meaning each infection from the virus can result in 1.4 to 3.9 new infections, when no members of the community are immune and no preventative measures, such as vaccination, are taken. By comparison, the median Ro value for SARS-CoV was in the range of 2 to 4 and for 1918 influenza was 1.80 .

\section{Immune responses induced by SARS-CoV-2}

The outcome of clinical infection likely largely depends on the capacity in mounting effective antiviral immune 
responses in time, to control viral spreading, to limit organ injuries and to speed up recovery. Here we summarize the immune response induced by $\mathrm{CoV}$.

\section{Innate and adaptive immunity}

Three components are crucial for SARS-CoV induced diseases: 1) the role of CD8+ T cells in defense against the virus, which causes apoptosis in the infected cells, 2) interactions of the virus with macrophages and dendritic cells, which initiate the early innate and subsequent adaptive immune responses, and 3) type I interferon (IFN) system, an innate response against viral infections, which can inhibit virus replication in the early phase.

Firstly, the central part of the body's anti-viral immunity is based on the interaction between antigen and antigen presentation cells (APC) when the virus enters the cells. The infected cells are recognized by virus-specific cytotoxic $\mathrm{T}$ lymphocytes (CTLs) via viral peptides as the antigen presented by major histocompatibility complex (MHC). The antigen presentation of virus mostly depends on MHC I molecules, but MHC II also has its contribution in some cases. The MHC I molecules display pieces of virus proteins on the surface of infected cells, which creates a signal to activate nearby CD8+ T cells to induce apoptosis in the infected cells. There are many reports on the relationship between various MHC polymorphisms and the susceptibility to SARS-CoV [13-15], but little is known about this association in COVID-19. Such information could provide beneficial aspects of personalized medicine for treatment or prevention of COVID-19.

Secondly, dendritic cells and macrophages are other first patrolling components of innate immune network, which play important roles in driving both innate and adaptive immune responses to the viral pathogens [16]. The invasion of viruses can be recognized by innate immune cells via pathogen-associated molecular patterns (PAMPs). In the case of $\mathrm{CoV}$, PAMPs are viral genomic RNA, which are recognized by endosomal RNA receptors such as TLR3, TR7, TR8, and TLR7 [17]. This can cause rapid responses of the innate immune cells to viruses, resulting in production of a large amount of type I IFN with antiviral functions.

Lastly, efficient innate immune responses against viruses also depend on type I IFN responses and downstream cascade. Type I IFN, by directly interfering with the viruses' replication ability, can prevent reproduction of viruses in infected cells. By mounting type I IFN responses successfully, viral replication and dissemination in an early stage are suppressed.

\section{Immune evasion}

SARS-CoV and MERS-CoV use several strategies to avoid the innate immune response, these are probably also employed by SARS-CoV-2. These include the inhibition of type I IFN recognition and signaling, as well as downregulation of MHC class I and class II molecules in infected macrophages or dendritic cells, resulting in impaired antigen presentation and diminished $\mathrm{T}$ cell activation. Moreover, some proteins encoded by SARS-CoV can interact with the signaling cascades downstream of the pattern recognition receptors.

\section{Humoral response}

After exposure to SARS-CoV-2, patients respond to the virus by generating specific IgM antibodies within a few days, followed by specific IgG production within a week $[3,6,18]$. In the case of SARS-CoV infection, although the serum anti-viral IgM antibody levels decline in a few months, the antiviral IgG antibody titers can persist for years. Among the many structural and non-structural proteins encoded by SARS-CoV-2, the $\mathrm{N}$ and S proteins are the most immunogenic antigens. Antibodies against the $\mathrm{N}$ protein are the first to appear and thus can serve as an early and reliable serum marker for virus exposure, whereas antibodies against the $\mathrm{S}$ protein develop later and can bind to the viral envelope. Recent studies indicated that the convalescent serum contains antibodies that can neutralize SARS-CoV-2 in cell cultures $[2,3]$. Therefore, IgG against the $\mathrm{S}$ protein is both a marker for viral exposure and an indicator of recovery.

\section{Potential role of antibody-dependent enhancement (ADE) in SARS-CoV2 infection}

The potential risk of disease exacerbation by ADE, a phenomenon in which pre-existing poorly neutralizing antibodies lead to enhanced infection, has been a serious concern for vaccine development and antibody-based therapeutic strategy. Compared to the ADE in dengue viral infections, which was supported by a great deal of epidemiological and clinical evidence in the past four decades [19], this phenomenon in coronaviruses has mainly been observed in cell-based experimental models $[20,21]$.

To illustrate this further by also using dengue virus as an example: while more severe symptoms, such as dengue hemorrhagic fever (DHF)/dengue shock syndrome (DSS), can be observed during primary infection, they are much more frequently developed following a secondary infection with a different serotype (out of the four existing serotypes) [19]. Furthermore, it has been well documented that the high level of virus replication seen during secondary infection with a heterotypic virus is a direct consequence of ADE of viral replication. This is mediated primarily by the pre-existing, non-neutralizing, or sub-neutralizing antibodies to the virion surface antigens, resulting in enhanced access to target cells, through binding of the virion-antibody complexes to 
IgG Fc receptors $(\mathrm{Fc} \gamma \mathrm{R})$ on these cells [19]. This common underlying theme of ADE-based magnification of virus replication also indicates that severe disease is not merely attributable to inherent virulence of virus [22].

Interestingly, as described in a later section, several available evidence from the use of convalescent sera in patients with SARS, MERS [23] and 245 cases with COVID-19 [24] suggest the feasibility and safety of convalescent serum trials. Here, caution and vigilance to identify any evidence of enhanced coronavirus infection by ADE will be required. Despite the fact epidemiological and clinical observations supportive of existence of $\mathrm{ADE}$ in coronavirus infection is not available, a molecular mechanism behind ADE of coronavirus has currently been provided [21]. The authors demonstrated that a neutralizing antibody binds to the $\mathrm{S}$ protein of coronaviruses like a viral receptor, triggering a conformational change of the spike and mediating a viral entry into $\mathrm{Fc} \gamma \mathrm{R}$-expressing cells through canonical viralreceptor-dependent pathways. However, an enhanced entry of these pseudovirus-based approaches does not support directly the magnification of viral replication in these cells. Compared to dengue viruses, these Fc $\gamma R$ bearing cells such as dendritic cells, monocytes and macrophages, even if infected through ADE process, would presumably not be so "permissive" for coronaviruses, in terms of their replication and assembly. However, these viewpoints need further investigation.

Apparently, many host factors could also exacerbate disease during secondary infection. These host factors need to be identified by combined epidemiological and genetic analyses of appropriate patients, and the contribution of underlying host factors to the control of coronavirus replication needs to be determined. For example, ADE of replication can possibly occur with the vaccine strains of viruses in the endemic populations, such as attenuated or recombinant coronavirus vaccines. However, the level of replication will likely remain low, and thus this small enhancement of replication will probably not augment the disease. In addition, this could result in heightened vaccine immunogenicity due to a small increase in the virus load. However, further investigation on correlations between immunological responses and disease outcome and the validation of these findings in vaccine trials will be invaluable for developing safe and effective SARS-CoV2 vaccines (see below).

\section{Cytokine and pathologic characteristics of COVID-19}

While SARS-CoV can evade innate immune system, they can also induce intensive inflammatory reactions through innate immune cells. In fact, SARS-CoV and SARS-CoV-2 infections are known to activate a massive over-production of cytokines by the host immune system - a phenomenon known as "cytokine storm", which usually occurs a few days after the onset of the illness. This also results in increased local and systemic vascular permeability in major organs. Cytokine storm is reported in many viral infections, and contributes significantly to the pathogenesis and severity of acute viral infections.

The tissue tropism of each virus determines the cytokine profiles of virus-induced cytokine storm (reviewed in [25]). For example, macrophages produce a higher amount of proinflammatory cytokines than endothelial cells, while virus-infected endothelial cells are the major source of chemokines. However, this may not be generalizable, and it is crucial to elucidate the tropism of SARS-CoV-2 in order to interpret the data.

Most proinflammatory cytokines are released from macrophages and severe acute infections are usually associated with the activation of macrophages by enveloped viruses. In addition, activation of neutrophils may also be involved. As mentioned above, viral nucleic acids can induce the production of interferons and proinflammatory cytokines, through engaging endosomal TLRs. These intracellular nucleic acid receptors/sensors have been defined as "protective host factors", as they are critical for host defense against viral infections. However, the identity and contribution of "pathogenic host factors" to virus-induced severe inflammatory reactions and lethality, and how different viruses cause distinct clinical symptoms, remain unclear.

Some available information related to the cytokine storm induced by SARS-CoV and MERS-CoV is summarized below. It is to be noted that while both SARS-CoV and SARS-CoV-2 utilize ACE-2 as their receptors, MERS-CoV binds to the receptor dipeptidyl peptidase 4 (DPP4/CD26). The differences in receptor usage may account for the differences in disease patterns, including the organs involved and the extent of the cytokine storm induced.

\section{SARS-CoV}

SARS-CoV infection can cause ARDS and high mortality [26-28]. The clinical course of this infection has three phases: 1) robust virus replication accompanied by fever in the first few days; 2) high fever and pneumonia with progressive decline of virus titers; 3) ARDS resulting from active host immune responses in the absence of detectable viruses [1]. In addition to infecting and proliferating in the airways and alveolar epithelial cells, SARS$\mathrm{CoV}$ can also infect dendritic cells, monocytes, and macrophages, without undergoing proliferation (i.e., abortive infection) [29]. SARS-CoV-infected epithelial cells produce high levels of chemokines such as CCL2, CCL3, CCL5, and CXCL10. In addition, SARS-CoV-infected dendritic cells [30,31] and macrophages [29] secrete 
high levels of proinflammatory cytokines TNF and IL-6, and significant amounts of chemokines.

It is interesting to note that higher levels of IL-1, IL12, IFN-gamma, IL-8, and CXCL9, in addition to the cytokines and chemokines mentioned above, were also observed in SARS patients with severe diseases. This suggests that other cell types also contribute to SARS$\mathrm{CoV}$-induced cytokine storm. The typical pathological changes in the lungs include focal hemorrhage and mucopurulent materials in bronchial trees with diffuse alveolar damage. Histological examination shows extensive macrophage and neutrophil infiltration with lower levels of $\mathrm{T}$ lymphocytes. Existing information suggests that the SARS-CoV-infected airways and alveolar epithelial cells secrete abundant chemokines to attract immune cell infiltrations to the lungs, including macrophages and neutrophils, thereby causing damage due to high levels of proinflammatory cytokines and other mediators secreted by these cell types.

\section{MERS-CoV}

In addition to the airway epithelial cells, MERS-CoV can also replicate in human monocytes, macrophages, dendritic cells, and activated $\mathrm{T}$ cells. The typical lung pathological changes caused by MERS-CoV is diffuse alveolar damage. In addition, pleural and pericardial effusions associated with generalized congestion and consolidation of lungs have been noted [32], and the severity of lung lesions were noted to be correlated with extensive infiltration of neutrophils and macrophages [32]. Similar to SARS-CoV, MERS-CoV can induce high levels of proinflammatory cytokines and chemokines in human monocyte-derived macrophages and dendritic cells. MERS-CoV infection was also reported to induce increased concentrations of proinflammatory cytokines (IFN- $\gamma$, TNF- $\alpha$, IL15, and IL17), [33]. The high serum cytokine and chemokine levels in MERS patients were correlated with increased infiltration of neutrophil and monocytes along with severe tissue damage in the lungs [32, 34, 35]. Thus, the pathological change in the lungs is similar between SARS-CoV and MERS-CoV. Whereas, the higher mortality rate in MERS-CoV-infected patients may be due to the higher incidence of pericarditis in infected patients.

\section{SARS-CoV-2}

The first autopsy of COVID-19 victims along with immuno-histological staining revealed the presence of SARS-CoV-2 in the airway epithelia and macrophages, suggesting that the virus can infect both epithelial cells and macrophages [36]. The majority of infiltrating cells are macrophages and monocytes with moderate amounts of multinucleated giant cells and neutrophils. Increased levels of cytokines and chemokines, including
IL-2, IL-7, G-CSF, M-CSF, IFN- $\gamma$, IP-10, MCP-1, MIP$1 \alpha$, and TNF- $\alpha$, were detected in the plasma of COVID19 patients [37]. The most significant predictors of mortality in these patients are serum ferritin level and IL-6, suggesting that mortality is due to virus-induced hyperinflammation and cytokine storm during viral infection $[38,39]$.

Compared to the low pathogenic coronaviruses, the common features of high pathogenic coronaviruses include extensive infiltration of leukocytes, which secrete abundant proinflammatory cytokines and other chemical mediators to cause diffuse alveolar damage. Also, high pathogenic viruses are associated with abortive infection; for example, in contrast to the less pathogenic strain of influenza virus $\mathrm{H} 1 \mathrm{~N} 1$, the highly pathogenic influenza virus $\mathrm{H} 5 \mathrm{~N} 1$ does not replicate in macrophages; the latter is also a more potent inducer of the chemokine CXCL10 [40] The key innate immunity receptors/sensors responsible for high pathogenic coronavirus-induced proinflammatory cytokines are still unclear. Finally, notably, more deaths from COVID-19 have been caused by multiple organ dysfunction syndrome rather than respiratory failure, which is different from infections caused by SARS-CoV and MERS-CoV; the basis for this remains unknown.

\section{Diagnosis of infection by SARS-CoV-2}

Detection of viral RNA in the secretions from the respiratory tract of infected patients by reverse transcription-polymerase chain reaction (RT-PCR) test is currently the standard method for diagnosis of COVID19. They have some limitations, including long turnaround time (typically $2-4 \mathrm{~h}$ ) and the requirement of specialized facilities. Scientists around the world have been devoting effort to developing improved nucleic acid-based, simpler and faster methods. The US FDA issued an emergency-use authorization to Cepheid's Xpert Xpress SARS-CoV-2 test, which became the first pointof-care COVID-19 diagnostic test to receive this designation in the US. The test is designed to use the company's automated GeneXpert Systems and has a turnaround time of approximately $45 \mathrm{~min}$. Another prominent example is a method for detection of SARSCoV-2 by using CRISPR technologies [41]. These newly developed platforms will clearly require clinical testing before approval for routine use.

Tests based on antibodies are obviously another option for diagnosis and screening. Immediately after infections, viral genome and proteins start to increase, becoming the earliest markers for diagnosis within days. As the host immune responses gear up to confront and reduce viral replications, the viral RNA or antigen level declines, but the antiviral IgM and IgG titers rise up. As patients usually present themselves with cough, fever or 
shortness of breath, and are already beyond the early stage of infection [10]; here, nucleic acid tests are expected to pick up only a proportion of patients. A complementary serological test for specific IgM or IgG will help identify the rest. One report from Shenzhen studied 173 patients within 7 days of illness, who were later diagnosed with COVID-19 [42]; in this study RT-PCR could detect two-thirds of the patients, but only $45 \%$ tested positive even after 15 days. In contrast, although the serological positive rate within 1 week was less than $40 \%$, the rate increased to $100 \%$ after day 15 of disease onset. A combination of nucleic acid and serological test significantly increased the diagnosis rate from 66 to $78 \%$ even within 1 week of illness [42]. If these results can be validated, such a combination may become a standard clinical practice in the future. In this regard, Li et al., developed an immunoassay that can detect IgM and IgG antibodies against SARS-CoV-2 in human blood within $15 \mathrm{~min}$. They tested samples from close to 400 confirmed patients and over 100 negatively-tested patients at 8 different clinical sites and reported a sensitivity of over $88 \%$ and specificity of over $90 \%$ [43].

In the early stage (containment) of COVID-19 pandemic, there was a strong interest for rapid diagnosis and thus prototypes of rapid viral antigen or antibody tests were being developed for point-of-care use. These platforms have the advantage of convenience and a fast turnaround time, but suffer from inadequate sensitivity and specificity, as compared with standard RT-PCR. Hence, their results need to be interpreted with caution. Preparation of high-quality antibodies and antigens requires years in perfecting such point-of-care tests, judging from the experience in developing such tests for influenza viruses. Eventually, the more stringent criteria for a definitive diagnosis will need paired serum samples to demonstrate a true seroconversion [6].

Finally, the issue of antibody cross-reactivity with other human coronaviruses warrants discussion. As mentioned above, serological assays usually adopt viral $\mathrm{N}$ or $\mathrm{S}$ protein as antigens and the protein components from all four human coronaviruses that cause common cold show very limited sequence homology with those of SARS-CoV-2. Thus, despite the fact the majority of the populations have been exposed to the four low pathogenic human coronaviruses, their sera do not react positively in SARS-CoV-2 ELISA [6, 18]. While MERS-CoV is also more distally related and presents no concerns, the situation for SARS-CoV-exposed patients is different. As the $\mathrm{N}$ and $\mathrm{S}$ proteins of the SARS-CoV strain share high homology (70-90\%) with those of SARS-CoV-2, serum from SARS patients can actually cross-react with SARS-CoV-2 $\mathrm{N}$ or $\mathrm{S}$ protein in immunoblot or viral neutralization assays $[2,3]$. However, as SARS-CoV epidemic was only transient with a very small proportion of the populations being exposed, this cross-reactivity should not be an important issue.

\section{Vaccination for prevention of COVID-19}

As with many vaccine-preventable viral diseases like measles and chicken pox, the newly emerged SARS$\mathrm{CoV}-2$ infection assumes an epidemiological characteristic capable of evading containment measures and facilitating pandemic potential. Thus, a high proportion of undetected infections with mild or no symptoms can efficiently sustain viral transmission [44]. While containment and lockdown can serve as temporary control measures, effective vaccines or therapeutic agents are much needed for the ultimate control of the disease. The vaccine research and development thus far have progressed at an unprecedented speed; the first dose of RNA-based SARS-CoV-2 vaccine was administered to test its safety in humans on March 16, 2020, only 2 months after the new virus was first identified. Such rapid progress was facilitated by a combination of multiple factors, including advances in vaccine research on SARS and MERS, as recently reviewed [45], progress in a number of vaccine technology platforms to the early stage of human trial [46-48], and readily available support from the well-orchestrated international collective effort of the Coalition for Epidemic Preparedness Innovations (CEPI) [49]. The aforementioned innovative aspects that could potentially drive SARS-COV-2 vaccine development to market launch within a year or two are summarized below.

\section{Target antigen of coronavirus}

The coronavirus $\mathrm{S}$ protein is a critical target for antiviral neutralizing antibodies and functions to mediate entry into mammalian cell expressing the viral receptor ACE2 $[3,50]$. Moreover, the target neutralizing epitope of SARS-CoV was further narrowed to a smaller fragment of the $\mathrm{S}$ protein, later termed receptor binding domain (RBD) [51]. Building on these paradigmatic scientific advances that the $S$ protein is the putative target antigen, SARS-CoV-2 vaccine candidates are designed to include full or various lengths of the $S$ protein focusing on the RBD. Vaccine based on the whole virus may be less preferred due to its association with eosinophilic pulmonary pathology $[52,53]$.

\section{Vaccine technology platform}

A number of novel vaccine platforms, including vector-, DNA-, and RNA-based vaccines, are being developed or improved with innovative technology specifically to combat pandemic-prone outbreaks and have been recently reviewed [54]. Nucleic acid vaccines, including both DNA and RNA, offer the potential to accurately express any protein antigen in host cells and to present the 
antigen closely resembling antigen expression and presentation during viral infection. DNA vaccines against MERS and RNA vaccine against H7N9 have completed phase I trials that showed these platforms to be safe [46-48]. The nucleic acid vaccine can be completely synthetic and formulated within a few weeks at sufficient quantities to support clinical trials - a valuable feature when facing potential pandemic. Vector-based vaccine consists of a target antigen inserted into a viral genome to render faithful antigen generation, targeting and processing in vivo after vaccination. The first Ebola vaccine approved by US FDA is a vector-based vaccine using vesicular stomatitis virus expressing a surface glycoprotein of Ebola [55], thus supporting the applicability of this platform in combating emerging infectious diseases. These platforms offer versatile adaptation for antigen of new diseases, and the process development for production is relatively simple and quick, indicating the value of these platforms for the urgent response to new diseases.

\section{Funding and coordination}

The rapid infusion of funding from and coordination by CEPI in January 2020 was the major driver for the speed of SARS-CoV-2 vaccine R\&D progress (Fig. 1). With its mission being "to stimulate, finance, and coordinate the development of vaccines for epidemic diseases" especially aiming to drive vaccine innovation for highpriority public health threats, CEPI has supported a number of "technology platforms". These included a vaccine printer, molecular clamp technology for protein production, and a self-amplifying RNA vaccine platform since 2017 (CEPI web page https://cepi.net/research dev/technology/). An innovated vaccine platform technology pertains to a system that uses the same basic core technological components as a backbone and can be adapted by inserting new genetic or protein sequences to target newly emerging pathogens. It is with the application of this concept that an RNA-based SARS-CoV-2 vaccine, built on the avian flu vaccine platform [46], is expected to be developed and quickly proceed to human trial within only a few months since COVID-19 became an epidemic, and a DNA-based vaccine candidate modeling that of MERS is soon to follow [46]. The CEPI coordinated effort encompassing a wide range of available technologies from industry and research institutes globally has shown preliminary success toward an urgent response to control a pandemic.

Immunopathology and potential adverse effects

While coronavirus antigens that induce protective neutralizing antibodies have been identified, coronavirus vaccines also present a unique problem in that immunized individuals when infected by virus can develop lung eosinophilic pathology [53, 56]; this seems to be either exacerbated or eliminated by the formulation of adjuvant selection depending on the Th1/Th2 bias and induction of durable IFN- $\gamma$ responses, respectively [57].

CEPI Coordinated COVID-19 Vaccine Projects

\begin{tabular}{|c|c|}
\hline $\operatorname{Jan} 23$ & $\begin{array}{l}\text { University Queensland - molecular clamp } \\
\text { Inovio Pharm - DNA } \\
\text { Moderna Inc - RNA } \\
\text { (NIH and others for further studies) }\end{array}$ \\
\hline $\operatorname{Jan} 31$ & CureVac - RNA Printer"it lipid nanoparticle (LNP) \\
\hline Feb 3 & GSK - adjuvant \\
\hline Feb 4 & CSIRO - Animal study; scale up Production \\
\hline Mar 3 & DynaVax technology - CpG adjuvant \\
\hline Mar 10 & $\begin{array}{l}\text { Hong Kong University - Modified nasal spray } \\
\text { NovaVax - Protein-coupled nanoparticles }\end{array}$ \\
\hline Mar 16 & Moderna vaccine trial begins \\
\hline Mar 18 & Oxford - ChAdOx1 vector vaccine \\
\hline
\end{tabular}

Fig. 1 CEPI coordinated COVID-19 vaccine projects. Ref: CEPI website news https://cepi.net/news/ 
In addition, $\mathrm{ADE}$, described above, was seen in the lungs of macaques after administration of inactivated SARS$\mathrm{CoV}$ vaccine or vaccine composed of certain $\mathrm{S}$ antigen fragments [58]. These studies highlight the importance of designing the target antigen and selection of adjuvants to ensure both efficacy and safety. Considering the novel nature of SARS-CoV-2 and that an animal model has yet to be established for testing of the vaccine to especially focus on the immunopathological perspectives, the safety concern is anticipated to present most of the hurdles in the development process.

\section{Herd immunity}

Herd immunity refers to a state when sufficient proportion of a population becomes immune to SARS-CoV-2, via natural infection or vaccination, so as to eventually halt further spread of disease, and thus individuals not immune to the virus are protected. In the case of COVID-19, the herd immunity was estimated to be $60 \%$ of the population. Before vaccines are available for mass immunization, the strategy of achieving herd immunity via natural infection has been considered and deemed not advisable when a number of factors were considered. Thus, self-isolation and social distancing remain crucial in combating this pandemic so that the initial pressure on our healthcare systems is reduced, and more time is given to us to develop vaccines or effective therapies.

\section{Immunological approaches to treatment of COVID-19}

The disease spectrum of COVID-19 can be divided into mild infection, pneumonia, ARDS, and even multiple organ failure [37]. After a decade of research on coronavirus, unfortunately, still there are no licensed vaccines, effective specific antivirals, nor drug combinations supported by high-level evidence to treat the infection, especially for newly emerging strains such as SARS-COV-2 [59]. Several strategies are being considered for the treatment of COVID-19, including the use of antimicrobial agents, immunotherapy with virus-specific antibodies in convalescent plasma, monoclonal and polyclonal antibodies produced in vitro or genetically modified antibodies, and interferons. Here we focus on immunebased therapies, but for the sake of completeness, we also include therapies using antimicrobial agents as 7 supplementary information. The potential interventions for SARS-CoV infection are summarized in Table 1.

\section{Monoclonal and polyclonal antibodies targeting CoV}

Biologic drugs composed of monoclonal antibodies (mAbs) have been developed for treatment of a variety of diseases. It is thus not surprising that this approach is being considered for the treatment of SARS-CoV infection and shows promise. A human IgG1 mAb, CR3022, that binds to SARS-CoV S protein has been developed [70]. Sui et al. found one recombinant human mAb (single-chain variable region fragment, scFv, 80R) against the S1 domain of S protein of SARS-CoV from two nonimmune human antibody libraries. The mAb could efficiently neutralize SARS-CoV and inhibit syncytia formation between cells expressing $S$ protein and those expressing the SARS-CoV receptor ACE2 [71]. A human IgG1 mAb, CR3014, has been generated and found to be able to neutralize SARS-CoV and shown to be able to prevent SARS-CoV infection in ferrets [72].

More recently, Ju et al. reported the isolation and characterization of 206 RBD-specific mAbs derived from single B cells of eight SARS-CoV-2 infected individuals [79]. For clones from one patient they demonstrated their ability to neutralize live SARS-CoV-2. None of these antibodies cross-reacted with RBDs from either SARS-CoV or MERS-CoV, although the patient plasma exhibited such cross-reactivity. These neutralizing antibodies have the potential to be used for prophylaxis for or treatment of SARS-CoV-2 infection.

Agents that directly block the binding of $\mathrm{S}$ protein to the functional receptor ACE2 also have the potential to be used for prevention of COVID-19. Guillon et al. demonstrated that binding of SARS-CoV S protein to ACE2 could be inhibited by anti-histo-blood group antibodies, presumably because the virus carries histo-blood group antigen structures of the host [4]. While whether this approach can be developed into effective treatment strategies is uncertain, the findings have a bearing on the effect of the naturally occurring anti-histo-blood group antibodies on the individual variations in susceptibility to SARS-CoV infection.

\section{Convalescent plasma}

Convalescent plasma can be employed for passive immunotherapy and is usually chosen when there are no specific vaccines or drugs available for emerging infection-related diseases. Yeh et al. reported a favorable outcome in the use of convalescent plasma for treatment of SARS-CoV-infected healthcare workers [73]. Arabi et al. tested the feasibility of convalescent plasma therapy as well as its safety and clinical efficacy in critically ill patients suffering from MERS-CoV infection [74, 80]. If available, convalescent plasma could certainly be considered for the treatment of SARS-CoV-2-infected critically ill patients.

\section{Interferons}

Interferons (IFNs), including IFN- $\alpha$ and IFN $-\beta$, are produced during the innate immune response to virus infection and they are able to inhibit the replication of virus in vitro $[75,81]$. As mentioned above, IFN transcription was blocked in tissue cells infected with SARS-CoV. 
Table 1 Potential therapeutic agents for COVID-19

\begin{tabular}{|c|c|c|c|}
\hline Drug/agents & Evidence level & Mechanisms & Reference \\
\hline Serine protease TMPRSS2 & cell & $\begin{array}{l}\text { binds the viral spike }(S) \text { protein, leading to S protein } \\
\text { priming by host } \\
\text { cell protease via receptor ACE2 }\end{array}$ & {$[60]$} \\
\hline $\begin{array}{l}\text { Serotonin receptor antagonist } \\
\text { cinanserin }\end{array}$ & cell & inhibits the 3 chymotrypsin-like (3C-like) protease & [61] \\
\hline $\begin{array}{l}\text { S protein-angiotensin-converting } \\
\text { enzyme-2 (ACE2) blockers }\end{array}$ & cell & blocks the binding of $\mathrm{S}$ protein to ACE2 & [4] \\
\hline $\begin{array}{l}\text { Antimalarial } \\
\text { chloroquine }\end{array}$ & clinical use & $\begin{array}{l}\text { inhibits the fusion between viral envelope and endosomal/ } \\
\text { lysosomal membranes }\end{array}$ & [62] \\
\hline $\begin{array}{l}\text { Protease inhibitors } \\
\text { lopinavir/ritonavir } \\
\text { (HIV protease inhibitors) }\end{array}$ & clinical use & may possibly inhibit SARS-CoV-2 protease & [63] \\
\hline $\begin{array}{l}\text { Antiviral } \\
\text { ribavirin }\end{array}$ & cell & $\begin{array}{l}\text { may modulate host immunity and/or cause RNA } \\
\text { replication catastrophe }\end{array}$ & [64] \\
\hline $\begin{array}{l}\text { Protease inhibitors } \\
\text { nelfinavir }\end{array}$ & cell & a selective post-translational inhibitor & {$[65]$} \\
\hline Nucleotide analog prodrug remdesivir & $\begin{array}{l}\text { cell and clinical use (first case of } \\
\text { COVID-19 in the United States) }\end{array}$ & possible inhibitor of RNA replication & {$[66,67]$} \\
\hline Indole-derivative molecule arbidol & cell & $\begin{array}{l}\text { Inhibits fusion between viral envelope and cellular } \\
\text { membranes }\end{array}$ & [68] \\
\hline $\begin{array}{l}\text { Immunosuppressive agent } \\
\text { cyclosporine A }\end{array}$ & cell & block replication via inhibition of nucleocapsid protein & [69] \\
\hline Monoclonal antibody CR3022 & cell and clinical use & $\begin{array}{l}\text { potently binds } \\
\text { the receptor binding domain of } \mathrm{S} \text { protein }\end{array}$ & [70] \\
\hline $\begin{array}{l}\text { Monoclonal antibody single-chain vari- } \\
\text { able region fragments, scFv, } 80 R\end{array}$ & cell & acts against the $\mathrm{S} 1$ domain of $\mathrm{S}$ protein & [71] \\
\hline Monoclonal antibody CR3014 & cell & neutralization of viral infectivity & [72] \\
\hline $\begin{array}{l}\text { Immunotherapeutic potential } \\
\text { convalescent plasma }\end{array}$ & cell and clinical use & neutralization of viral infectivity & {$[73,74]$} \\
\hline $\begin{array}{l}\text { Interferons } \\
\text { IFN- } \alpha \text { and IFN- } \beta\end{array}$ & cell & $\begin{array}{l}\text { induction of interferon-stimulated genes to suppress viral } \\
\text { replication }\end{array}$ & {$[75,76]$} \\
\hline $\begin{array}{l}\text { Cytokine blocker } \\
\text { cytokine IL-37 }\end{array}$ & cell & $\begin{array}{l}\text { inhibits inflammation, by acting on mTOR and increasing } \\
\text { the activity of adenosine monophosphate kinase }\end{array}$ & [77] \\
\hline $\begin{array}{l}\text { Cytokine blocker } \\
\text { Lianhuaqingwen }\end{array}$ & cell & anti-inflammation; inhibits IL-6 receptor & [78] \\
\hline $\begin{array}{l}\text { Cytokine blocker } \\
\text { antibody against IL-6 receptor }\end{array}$ & Clinical use & anti-inflammation; inhibits IL-6 receptor & \\
\hline
\end{tabular}

Recombinant IFN- $\alpha$ given on 3 days before the infection could reduce viral replication and lung damage, as compared with the control in monkeys and in a pilot clinical trial [82]. IFN- $\alpha$ inhalation can also be considered. Combination of interferon- $\alpha-2 a$ with ribavirin was used in treatment of patients with severe MERS-CoV infection and the survival of these patients was improved [76, 83]. These findings suggest that these FDA-approved IFN's could be used for the treatment of COVID-19.

\section{Cytokine blockers}

As mentioned above, cytokine storm is the major underlying pathology in severe cases of COVID-19. Thus, neutralization of some of the major cytokines are considered as a novel approach for treatment of severely ill cases and reducing morbidity and mortality. Huang $\mathrm{C}$ et al. reported that increased IL-1ß, IFN- $\gamma$, IP-10, and MCP-1 in SARS-CoV-2 infection and higher concentrations of G-CSF, IP-10, MCP-1, MIP-1A, and TNF- $\alpha$ were found in patients requiring treatment at ICU than those not treated at ICU [37]. They also noted that cytokine storm was associated with disease severity. Conti $\mathrm{P}$ et al. reported that pro-inflammatory cytokines of interleukin (IL)- $1 \beta$ and IL- 6 in mild and acute respiratory syndrome are associated with development of lung fibrosis in COVID-19 [77]. Thus, suppression of proinflammatory IL-1 family members and IL- 6 might have a potential therapeutic effect. IL-37, an immunosuppressive cytokine, acts on mTOR and increases the activity of adenosine monophosphate kinase, which inhibits 
inflammation by suppressing production of multiple cytokines downstream of MyD88, including IL-1 $\beta$, IL-6, TNF and CCL2. IL-37 might be a potential therapeutic cytokine for inhibition of inflammation in COVID-19 [77]. Runfeng $\mathrm{L}$ et al. demonstrated that Lianhuaqingwen, a traditional Chinese medicine, significantly inhibited SARS-CoV-2 replication by suppressing mRNA of IL-6 and other pro-inflammatory cytokines in Vero E6 cells [78].

Cytokine blocker that target interleukin 6 receptor in COVID-19 could be potentially developed as therapeutic agents in future. In fact, FDA approved mAb against IL-6 receptor (IL-6R) is available for treatment of rheumatoid arthritis. The Society for Immunotherapy of Cancer has issued a statement on access to IL-6-targeting therapies for COVID-19. It is encouraging that pharmaceutical companies have in fact initiated clinical trials of anti-IL-6R for treatment of patients with severe COVID-19.

\section{Perspectives and conclusions}

There are still a large number of unanswered questions. How fast SARS-CoV-2 would mutate and would the mutated virus become more infectious or invasive. According to Andersen et al. [84], viruses constantly mutate, but those mutations do not typically make the virus more virulent or cause more serious disease. In fact, most mutations are detrimental to the virus or have no effect. There was a study of the SARS-CoV in primate cells suggesting that a mutation in this viral strain acquired during the 2003 SARS outbreak probably reduced virulence of the virus [85]. Another issue is whether SARS-CoV-2, unlike SARS-CoV and MERS-CoV will continue to cause epidemic or even behave like seasonal flu. In fact, we have already witnessed the second wave of outbreak occurring in North America and Europe, after the first wave that occurred in Asia, and COVID19 may bounce back-and-forth between north and south hemispheres, as influenza virus does each year.

Finally, factors that determine the individual susceptibility to COVID-19 remain to be elucidated. As mentioned above, there are many reports on the relationship between various MHC polymorphisms and the susceptibility to SARS-CoV. Also, what governs the development of severe illness, including cytokine storm, besides the pre-existence of certain diseases and age factor, awaits clarification. Despite these uncertainties, scientists in academia and industry around the world have moved at an unprecedented speed to develop improved methods for detection of the virus and treatment of the disease. Advancement in immunology over the years has certainly facilitated many of these developments. We shall witness some of the recent advancements in development of vaccines and biologics for treatment of various other serious illnesses being used for fighting against
COVID-19. We are hopeful these efforts will be sustained even after the pandemic is over, allowing us to be even more ready in the unfortunate event that another epidemic or pandemic, like COVID-19, takes place in the future.

\section{Supplementary information}

Supplementary information accompanies this paper at https://doi.org/10. 1186/s12929-020-00663-W.

Additional file 1. Supplemental information.

\section{Abbreviations}

ACE: Angiotensin converting enzyme; ADE: Antibody-dependent enhancement; CEPI: Coalition for Epidemic Preparedness Innovations; CoV: Coronavirus; COVID-19: Coronavirus disease 2019; FcyR: IgG Fc receptor; CSIRO: Commonwealth Scientific and Industrial Research Organization; ICU: Intensive care unit; IFN: Interferon; Ig: Immunoglobulin;

mAb: Monoclonal antibody; MERS: Middle East respiratory syndrome; MHC: Major histocompatibility complex; N protein: Nucleocapsid protein; RBD: Receptor-binding domain; RT-PCR: Reverse transcription-polymerase chain reaction; SARS: Severe acute respiratory syndrome; S protein: Spike protein; WHO: World health organization

\section{Acknowledgements}

The authors thank Dr. Ming-Hsiang Hong for his assistance in preparation of the manuscript.

\section{Authors' contributions}

The primary authors for the sections are as follows. FTL: Introduction, Epidemiology, Perspectives and conclusions; HCC: Immune responses induced by SARS-CoV-2; HKS: Potential role of antibody-dependent enhancement (ADE) in SARS-CoV2 infection; SLH: Cytokine and pathologic characteristics of COVID-19; PJC: Diagnosis of infection by SARS-CoV-2 PJC; MSH: Vaccination for prevention of COVID-19; FYC and JCL: Immunological approaches to treatment of COVID-19. FTL edited the manuscript. All authors read and approved the final manuscript.

Authors' information

None.

Funding

Not applicable.

Availability of data and materials

Not applicable.

Ethics approval and consent to participate

Not applicable

Consent for publication

Not applicable.

\section{Competing interests}

The authors declare that they have no competing interests.

\section{Author details}

${ }^{1}$ Division of Infectious Diseases and Tropical Medicine, Department of Internal Medicine, Tri-Service General Hospital, National Defense Medical Center, Taipei, Taiwan. ' Division of Rheumatology, Immunology, and Allergy, Department of Medicine, Tri-Service General Hospital, National Defense Medical Center, Taipei, Taiwan. ${ }^{3}$ Division of Gastroenterology, Department of Medicine, College of Medicine, National Taiwan University, Taipei, Taiwan. ${ }^{4}$ Institute of Biomedical Sciences, Academia Sinica, 128 Academia Road, Section 2, Taipei, Taiwan. ${ }^{5}$ Genomics Research Center, Academia Sinica, Taipei, Taiwan. ${ }^{6}$ National Institute of Infectious Diseases and Vaccinology, National Health Research Institutes, Zhunan, Miaoli County, Taiwan. 
Received: 31 March 2020 Accepted: 28 April 2020

Published online: 04 June 2020

\section{References}

1. Channappanavar R, Perlman S. Pathogenic human coronavirus infections: causes and consequences of cytokine storm and immunopathology. Semin Immunopathol. 2017:39(5):529-39.

2. Walls AC, Park YJ, Tortorici MA, Wall A, McGuire AT, Veesler D. Structure, function, and antigenicity of the SARS-CoV-2 spike glycoprotein. Cell. 2020; 181(2):281-92.

3. Zhou P, Yang XL, Wang XG, Hu B, Zhang L, Zhang W, Si HR, Zhu Y, Li B, Huang $C L$, Chen HD, Chen J, Luo Y, Guo H, Jiang RD, Liu MQ, Chen $Y$, Shen XR, Wang X, Zheng XS, Zhao K, Chen QJ, Deng F, Liu LL, Yan B, Zhan FX, Wang YY, Xiao GF, Shi ZL. A pneumonia outbreak associated with a new coronavirus of probable bat origin. Nature. 2020;579(7798):270-3.

4. Guillon P, Clement M, Sebille V, Rivain JG, Chou CF, Ruvoen-Clouet N, Le Pendu J. Inhibition of the interaction between the SARS-CoV spike protein and its cellular receptor by anti-histo-blood group antibodies. Glycobiology. 2008;18(12):1085-93.

5. Yan R, Zhang Y, Li Y, Xia L, Guo Y, Zhou Q. Structural basis for the recognition of the SARS-CoV-2 by full-length human ACE2. Science. 2020; 367(6485):1444-8.

6. Meyer B, Drosten C, Muller MA. Serological assays for emerging coronaviruses: challenges and pitfalls. Virus Res. 2014;194:175-83.

7. WHO. Update 49 - SARS case fatality ratio, incubation period. <https://www. who.int/csr/sars/archive/2003 05 07a/en/>. Accessed 29 March 2020.

8. WHO. Middle East respiratory syndrome coronavirus (MERS-CoV). <https:// www.who.int/emergencies/mers-cov/en/>. Accessed 29 March 2020.

9. Chan JF, Yuan S, Kok KH, To K.K, Chu H, Yang J, Xing F, Liu J, Yip CC, Poon RW, Tsoi HW, Lo SK, Chan KH, Poon VK, Chan WM, Ip JD, Cai JP, Cheng VC, Chen $\mathrm{H}$, Hui CK, Yuen KY. A familial cluster of pneumonia associated with the 2019 novel coronavirus indicating person-to-person transmission: a study of a family cluster. Lancet. 2020;395(10223):514-23.

10. Zhu N, Zhang D, Wang W, Li X, Yang B, Song J, Zhao X, Huang B, Shi W, Lu R, Niu P, Zhan F, Ma X, Wang D, Xu W, Wu G, Gao GF, Tan W. China Novel Coronavirus I. and Research T. A Novel Coronavirus from Patients with Pneumonia in China, 2019. N Engl J Med. 2020;382(8):727-33.

11. Wu JT, Leung K, Bushman M, Kishore N, Niehus R, de Salazar PM, Cowling BJ, Lipsitch M, Leung GM. Estimating clinical severity of COVID-19 from the transmission dynamics in Wuhan. China Nature Medicine. 2020;26:506-10.

12. Wu Z, McGoogan JM. Characteristics of and important lessons from the coronavirus disease 2019 (COVID-19) outbreak in China: summary of a report of 72314 cases from the Chinese Center for Disease Control and Prevention. JAMA. 2020.

13. Wang SF, Chen KH, Chen M, Li WY, Chen YJ, Tsao CH, Yen MY, Huang JC, Chen YM. Human-leukocyte antigen class I CW 1502 and class II DR 0301 genotypes are associated with resistance to severe acute respiratory syndrome (SARS) infection. Viral Immunol. 2011;24(5):421-6.

14. Keicho N, Itoyama S, Kashiwase K, Phi NC, Long HT, Ha LD, Ban W, Hoa BK, Hang NT, Hijikata M, Sakurada S, Satake M, Tokunaga K, Sasazuki T, Quy T. Association of human leukocyte antigen class II alleles with severe acute respiratory syndrome in the Vietnamese population. Hum Immunol. 2009; 70(7):527-31.

15. Hajeer $A H$, Balkhy $H$, Johani S, Yousef MZ, Arabi Y. Association of human leukocyte antigen class II alleles with severe Middle East respiratory syndrome-coronavirus infection. Ann Thoracic Med. 2016;11(3):211-3.

16. Ito T, Wang YH, Liu YJ. Plasmacytoid dendritic cell precursors/type I interferon-producing cells sense viral infection by toll-like receptor (TLR) 7 and TLR9. Springer Semin Immunopathol. 2005;26(3):221-9.

17. Akira S, Hemmi H. Recognition of pathogen-associated molecular patterns by TLR family. Immunol Lett. 2003:85(2):85-95.

18. Huang LR, Chiu CM, Yeh SH, Huang WH, Hsueh PR, Yang WZ, Yang JY, Su IJ, Chang SC, Chen PJ. Evaluation of antibody responses against SARS coronaviral nucleocapsid or spike proteins by immunoblotting or ELISA. J Med Virol. 2004;73(3):338-46.

19. Murphy BR, Whitehead SS. Immune response to dengue virus and prospects for a vaccine. Annu Rev Immunol. 2011;29:587-619.

20. Casadevall A, Pirofski LA. The convalescent sera option for containing COVID-19. J Clin Invest. 2020;30(4):1545-8.
21. Wan Y, Shang J, Sun S, Tai W, Chen J, Geng Q, He L, Chen Y, Wu J, Shi Z, Zhou Y, Du L, Li F. Molecular Mechanism for Antibody-Dependent Enhancement of Coronavirus Entry. J Virol. 2020;94:5.

22. Halstead SB. Pathogenesis of dengue: challenges to molecular biology. Science. 1988;239(4839):476-81.

23. Mair-Jenkins J, Saavedra-Campos M, Baillie JK, Cleary P, Khaw FM, Lim WS, Makki S, Rooney KD, Nguyen-Van-Tam JS, Beck CR, Convalescent Plasma Study G. The effectiveness of convalescent plasma and hyperimmune immunoglobulin for the treatment of severe acute respiratory infections of viral etiology: a systematic review and exploratory meta-analysis. J Infect Dis. 2015;211(1):80-90.

24. Xinhua. China puts 245 COVID-19 patients on convalescent plasma therapy. <http://www.xinhuanet.com/english/2020-02/28/c_138828177.htm>. Accessed 29 March 2020.

25. McFadden G, Mohamed MR, Rahman MM, Bartee E. Cytokine determinants of viral tropism. Nat Rev Immunol. 2009;9(9):645-55.

26. Drosten C, Gunther S, Preiser W, van der Werf S, Brodt HR, Becker S, Rabenau H, Panning M, Kolesnikova L, Fouchier RA, Berger A, Burguiere AM, Cinatl J, Eickmann M, Escriou N, Grywna K, Kramme S, Manuguerra JC, Muller S, Rickerts V, Sturmer M, Vieth S, Klenk HD, Osterhaus AD, Schmitz H, Doerr HW. Identification of a novel coronavirus in patients with severe acute respiratory syndrome. N Engl J Med. 2003;348(20):1967-76.

27. Kuiken $T$, Fouchier RA, Schutten M, Rimmelzwaan GF, van Amerongen G, van Riel D, Laman JD, de Jong T, van Doornum G, Lim W, Ling AE, Chan PK, Tam JS, Zambon MC, Gopal R, Drosten C, van der Werf S, Escriou N, Manuguerra JC, Stohr K, Peiris JS, Osterhaus AD. Newly discovered coronavirus as the primary cause of severe acute respiratory syndrome. Lancet. 2003;362(9380):263-70.

28. Peiris JS, Lai ST, Poon LL, Guan Y, Yam LY, Lim W, Nicholls J, Yee WK, Yan WW, Cheung MT, Cheng VC, Chan KH, Tsang DN, Yung RW, Ng TK, Yuen KY, group S.s. Coronavirus as a possible cause of severe acute respiratory syndrome. Lancet. 2003;361(9366):1319-25.

29. Cheung CY, Poon LL, Ng IH, Luk W, Sia SF, Wu MH, Chan KH, Yuen KY, Gordon S, Guan Y, Peiris JS. Cytokine responses in severe acute respiratory syndrome coronavirus-infected macrophages in vitro: possible relevance to pathogenesis. J Virol. 2005;79(12):7819-26.

30. Law HK, Cheung CY, Ng HY, Sia SF, Chan YO, Luk W, Nicholls JM, Peiris JS, Lau YL. Chemokine up-regulation in SARS-coronavirus-infected, monocytederived human dendritic cells. Blood. 2005;106(7):2366-74.

31. Ziegler T, Matikainen S, Ronkko E, Osterlund P, Sillanpaa M, Siren J, Fagerlund R, Immonen M, Melen K, Julkunen I. Severe acute respiratory syndrome coronavirus fails to activate cytokine-mediated innate immune responses in cultured human monocyte-derived dendritic cells. J Virol. 2005; 79(21):13800-5.

32. Ng DL, Al Hosani F, Keating MK, Gerber SI, Jones TL, Metcalfe MG, Tong S, Tao Y, Alami NN, Haynes LM, Mutei MA, Abdel-Wareth L, Uyeki TM, Swerdlow DL, Barakat M, Zaki SR. Clinicopathologic, Immunohistochemical, and Ultrastructural Findings of a Fatal Case of Middle East Respiratory Syndrome Coronavirus Infection in the United Arab Emirates, April 2014. Am J Pathol. 2016;186(3):652-8.

33. Wong CK, Lam CW, Wu AK, Ip WK, Lee NL, Chan IH, Lit LC, Hui DS, Chan $\mathrm{MH}$, Chung SS, Sung JJ. Plasma inflammatory cytokines and chemokines in severe acute respiratory syndrome. Clin Exp Immunol. 2004;136(1):95-103.

34. Kim ES, Choe PG, Park WB, Oh HS, Kim EJ, Nam EY, Na SH, Kim M, Song KH, Bang JH, Park SW, Kim HB, Kim NJ, Oh MD. Clinical progression and cytokine profiles of Middle East respiratory syndrome coronavirus infection. J Korean Med Sci. 2016:31(11):1717-25.

35. Min CK, Cheon S, Ha NY, Sohn KM, Kim Y, Aigerim A, Shin HM, Choi JY, Inn KS, Kim JH, Moon JY, Choi MS, Cho NH, Kim YS. Comparative and kinetic analysis of viral shedding and immunological responses in MERS patients representing a broad spectrum of disease severity. Sci Rep. 2016;6:25359.

36. Yao XH, Li TY, He ZC, Ping YF, Liu HW, Yu SC, Mou HM, Wang LH, Zhang HR, Fu WJ, Luo T, Liu F, Chen C, Xiao HL, Guo HT, Lin S, Xiang DF, Shi Y, Li QR, Huang X, Cui Y, Li XZ, Tang W, Pan PF, Huang XQ, Ding YQ, Bian XW. A pathological report of three COVID-19 cases by minimally invasive autopsies. Zhonghua Bing Li Xue Za Zhi. 2020;49(0):E009.

37. Huang C, Wang Y, Li X, Ren L, Zhao J, Hu Y, Zhang L, Fan G, Xu J, Gu X, Cheng Z, Yu T, Xia J, Wei Y, Wu W, Xie X, Yin W, Li H, Liu M, Xiao Y, Gao H, Guo L, Xie J, Wang G, Jiang R, Gao Z, Jin Q, Wang J, Cao B. Clinical features of patients infected with 2019 novel coronavirus in Wuhan. China Lancet. 2020;395(10223):497-506. 
38. Guo YR, Cao QD, Hong ZS, Tan YY, Chen SD, Jin HJ, Tan KS, Wang DY, Yan $Y$. The origin, transmission and clinical therapies on coronavirus disease 2019 (COVID-19) outbreak - an update on the status. Mil Med Res. 2020;7(1): 11.

39. Ruan Q, Yang K, Wang W, Jiang L, Song J. Clinical predictors of mortality due to COVID-19 based on an analysis of data of 150 patients from Wuhan. Intensive Care Med: China; 2020.

40. Chan RW, Leung CY, Nicholls JM, Peiris JS, Chan MC. Proinflammatory cytokine response and viral replication in mouse bone marrow derived macrophages infected with influenza H1N1 and H5N1 viruses. PLoS One. 2012;7(11):e51057.

41. Zhang F., Abudayyeh O.O. and Gootenberg J.S. A protocol for detection of COVID-19 using CRISPR diagnostics. <https://www.broadinstitute.org/files/ publications/special/COVID-19\%20detection\%20(updated).pdf>. Accessed 29 March 2020

42. Zhao J, Yuan Q, Wang H, Liu W, Liao X, Su Y, Wang X, Yuan J, Li T, Li J, Qian S, Hong C, Wang F, Liu Y, Wang Z, He Q, Li Z, He B, Zhang T, Ge S, Liu L, Zhang J, Xia N, Zhang Z. Antibody responses to SARS-CoV-2 in patients of novel coronavirus disease 2019. medRxiv. 2020;2003(2002):20030189.

43. Li Z, Yi Y, Luo X, Xiong N, Liu Y, Li S, Sun R, Wang Y, Hu B, Chen W, Zhang Y, Wang J, Huang B, Lin Y, Yang J, Cai W, Wang $X$, Cheng J, Chen Z, Sun K, Pan W, Zhan Z, Chen L, Ye F. Development and clinical application of a rapid IgM-lgG combined antibody test for SARS-CoV-2 infection diagnosis. J Med Virol. 2020.

44. Li R, Pei S, Chen B, Song Y, Zhang T, Yang W, Shaman J. Substantial undocumented infection facilitates the rapid dissemination of novel coronavirus (SARS-CoV2). Science. 2020;368(6490):489-93.

45. Prompetchara E, Ketloy C, Palaga T. Immune responses in COVID-19 and potential vaccines: lessons learned from SARS and MERS epidemic. Asian Pac J Allergy Immunol. 2020;38(1):1-9.

46. Bahl K, Senn JJ, Yuzhakov O, Bulychev A, Brito LA, Hassett KJ, Laska ME, Smith M, Almarsson O, Thompson J, Ribeiro AM, Watson M, Zaks T, Ciaramella G. Preclinical and clinical demonstration of immunogenicity by mRNA vaccines against H10N8 and H7N9 influenza viruses. Mol Ther. 2017; 25(6):1316-27.

47. Martin JE, Louder MK, Holman LA, Gordon IJ, Enama ME, Larkin BD, Andrews CA, Vogel L, Koup RA, Roederer M, Bailer RT, Gomez PL, Nason M, Mascola JR, Nabel GJ, Graham BS, Team VRCS. A SARS DNA vaccine induces neutralizing antibody and cellular immune responses in healthy adults in a phase I clinical trial. Vaccine. 2008;26(50):6338-43.

48. Modjarrad K, Roberts CC, Mills KT, Castellano AR, Paolino K, Muthumani K, Reuschel EL, Robb ML, Racine T, Oh MD, Lamarre C, Zaidi Fl, Boyer J, Kudchodkar SB, Jeong M, Darden JM, Park YK, Scott PT, Remigio C, Parikh AP, Wise MC, Patel A, Duperret EK, Kim KY, Choi H, White S, Bagarazzi M, May JM, Kane D, Lee H, Kobinger G, Michael NL, Weiner DB, Thomas SJ, Maslow JN. Safety and immunogenicity of an anti-Middle East respiratory syndrome coronavirus DNA vaccine: a phase 1, open-label, single-arm dose-escalation trial. Lancet Infect Dis. 2019;19(9):1013-22.

49. Gouglas D, Christodoulou M, Plotkin SA, Hatchett R. CEPI: driving Progress towards epidemic preparedness and response. Epidemiol Rev. 2019;41:28-33.

50. Li W, Moore MJ, Vasilieva N, Sui J, Wong SK, Berne MA, Somasundaran M, Sullivan JL, Luzuriaga K, Greenough TC, Choe H, Farzan M. Angiotensinconverting enzyme 2 is a functional receptor for the SARS coronavirus. Nature. 2003;426(6965):450-4

51. Wong SK, Li W, Moore MJ, Choe H, Farzan M. A 193-amino acid fragment of the SARS coronavirus $S$ protein efficiently binds angiotensin-converting enzyme 2. J Biol Chem. 2004;279(5):3197-201.

52. Agrawal AS, Tao X, Algaissi A, Garron T, Narayanan K, Peng BH, Couch RB, Tseng CT. Immunization with inactivated Middle East respiratory syndrome coronavirus vaccine leads to lung immunopathology on challenge with live virus. Hum Vaccin Immunother. 2016;12(9):2351-6.

53. Bolles $M$, Deming $D$, Long $K$, Agnihothram $S$, Whitmore A, Ferris $M$, Funkhouser W, Gralinski L, Totura A, Heise M, Baric RS. A double-inactivated severe acute respiratory syndrome coronavirus vaccine provides incomplete protection in mice and induces increased eosinophilic proinflammatory pulmonary response upon challenge. J Virol. 2011;85(23):12201-15.

54. Rauch S, Jasny E, Schmidt KE, Petsch B. New vaccine technologies to combat outbreak situations. Front Immunol. 2018;9:1963.

55. Marzi A, Robertson SJ, Haddock E, Feldmann F, Hanley PW, Scott DP, Strong JE, Kobinger G, Best SM, Feldmann H. Ebola Vaccine VSV-EBOV rapidly protects macaques against infection with the 2014/15 Ebola virus outbreak strain. Science. 2015;349(6249):739-42.

56. Honda-Okubo Y, Barnard D, Ong CH, Peng BH, Tseng CT, Petrovsky N. Severe acute respiratory syndrome-associated coronavirus vaccines formulated with delta inulin adjuvants provide enhanced protection while ameliorating lung eosinophilic immunopathology. J Virol. 2015;89(6):2995-3007.

57. Sekimukai H, Iwata-Yoshikawa N, Fukushi S, Tani H, Kataoka M, Suzuki T, Hasegawa H, Niikura K, Arai K, Nagata N. Gold nanoparticle-adjuvanted S protein induces a strong antigen-specific lgG response against severe acute respiratory syndrome-related coronavirus infection, but fails to induce protective antibodies and limit eosinophilic infiltration in lungs. Microbiol Immunol. 2020;64(1):33-51.

58. Wang Q, Zhang L, Kuwahara K, Li L, Liu Z, Li T, Zhu H, Liu J, Xu Y, Xie J, Morioka H, Sakaguchi N, Qin C, Liu G. Immunodominant SARS coronavirus epitopes in humans elicited both enhancing and neutralizing effects on infection in non-human primates. ACS Infect Dis. 2016;2(5):361-76.

59. Dyall J, Gross R, Kindrachuk J, Johnson RF, Olinger GG Jr, Hensley LE, Frieman MB, Jahrling PB. Middle East respiratory syndrome and severe acute respiratory syndrome: current therapeutic options and potential targets for novel therapies. Drugs. 2017;77(18):1935-66.

60. Hoffmann M, Kleine-Weber H, Schroeder S, Kruger N, Herrler T, Erichsen S, Schiergens TS, Herrler G, Wu NH, Nitsche A, Muller MA, Drosten C, Pohlmann S. SARS-CoV-2 cell entry depends on ACE2 and TMPRSS2 and is blocked by a clinically proven protease inhibitor. Cell. 2020;181(2):271-80.

61. Chiow KH, Phoon MC, Putti T, Tan BK, Chow VT. Evaluation of antiviral activities of Houttuynia cordata Thunb. extract, quercetin, quercetrin and cinanserin on murine coronavirus and dengue virus infection. Asian Pac J Trop Med. 2016;9(1):1-7.

62. Dong L, Hu S, Gao J. Discovering drugs to treat coronavirus disease 2019 (COVID-19). Drug Discov Ther. 2020;14(1):58-60.

63. Chan KW, Wong VT, Tang SCW. COVID-19: an update on the epidemiological, clinical, preventive and therapeutic evidence and guidelines of integrative Chinese-Western medicine for the management of 2019 novel coronavirus disease. Am J Chin Med. 2020;13:1-26.

64. Morgenstern B, Michaelis M, Baer PC, Doerr HW, Cinatl J Jr. Ribavirin and interferon-beta synergistically inhibit SARS-associated coronavirus replication in animal and human cell lines. Biochem Biophys Res Commun. 2005;326(4): 905-8.

65. Hsieh LE, Lin CN, Su BL, Jan TR, Chen CM, Wang CH, Lin DS, Lin CT, Chueh LL. Synergistic antiviral effect of Galanthus nivalis agglutinin and nelfinavir against feline coronavirus. Antivir Res. 2010;88(1):25-30.

66. Holshue ML, DeBolt C, Lindquist $\mathrm{S}$, Lofy KH, Wiesman J, Bruce H, Spitters $C$, Ericson K, Wilkerson S, Tural A, Diaz G, Cohn A, Fox L, Patel A, Gerber SI, Kim L, Tong S, Lu X, Lindstrom S, Pallansch MA, Weldon WC, Biggs HM, Uyeki TM, Pillai SK, Washington State -nCo V.C.I.T. First Case of 2019 Novel Coronavirus in the United States. N Engl J Med. 2020;382(10):929-36.

67. Wang M, Cao R, Zhang L, Yang X, Liu J, Xu M, Shi Z, Hu Z, Zhong W, Xiao G. Remdesivir and chloroquine effectively inhibit the recently emerged novel coronavirus (2019-nCoV) in vitro. Cell Res. 2020;30(3):269-71.

68. Lu H. Drug treatment options for the 2019-new coronavirus (2019-nCoV). Biosci Trends. 2020;14(1):69-71.

69. Li HS, Kuok DIT, Cheung MC, Ng MMT, Ng KC, Hui KPY, Peiris JSM, Chan MCW, Nicholls JM. Effect of interferon alpha and cyclosporine treatment separately and in combination on Middle East respiratory syndrome coronavirus (MERS-CoV) replication in a human in-vitro and ex-vivo culture model. Antivir Res. 2018;155:89-96.

70. Tian X, Li C, Huang A, Xia S, Lu S, Shi Z, Lu L, Jiang S, Yang Z, Wu Y, Ying T. Potent binding of 2019 novel coronavirus spike protein by a SARS coronavirus-specific human monoclonal antibody. Emerg Microbes Infect. 2020;9(1):382-5.

71. Sui J, Li W, Murakami A, Tamin A, Matthews LJ, Wong SK, Moore MJ, Tallarico AS, Olurinde $M$, Choe $H$, Anderson $\amalg$, Bellini WJ, Farzan M, Marasco WA. Potent neutralization of severe acute respiratory syndrome (SARS) coronavirus by a human mAb to S1 protein that blocks receptor association. Proc Natl Acad Sci U S A. 2004;101(8):2536-41.

72. ter Meulen J, van den Brink EN, Poon LL, Marissen WE, Leung CS, Cox F Cheung CY, Bakker AQ, Bogaards JA, van Deventer E, Preiser W, Doerr HW, Chow VT, de Kruif J, Peiris JS, Goudsmit J. Human monoclonal antibody combination against SARS coronavirus: synergy and coverage of escape mutants. PLoS Med. 2006;3(7):e237. 
73. Yeh KM, Chiueh TS, Siu LK, Lin JC, Chan PK, Peng MY, Wan HL, Chen JH, Hu $\mathrm{BS}$, Perng CL, Lu JJ, Chang FY. Experience of using convalescent plasma for severe acute respiratory syndrome among healthcare workers in a Taiwan hospital. J Antimicrob Chemother. 2005;56(5):919-22.

74. Chen L, Xiong J, Bao L, Shi Y. Convalescent plasma as a potential therapy for COVID-19. Lancet Infect Dis. 2020;20:398-400.

75. Zhang Q, Yoo D. Immune evasion of porcine enteric coronaviruses and viral modulation of antiviral innate signaling. Virus Res. 2016;226:128-41.

76. Lee JY, Bae S, Myoung J. Middle East respiratory syndrome coronavirusencoded ORF8b strongly antagonizes IFN-beta promoter activation: its implication for vaccine design. J Microbiol. 2019;57(9):803-11.

77. Conti P, Ronconi G, Caraffa A, Gallenga CE, Ross R, Frydas I, Kritas SK. Induction of pro-inflammatory cytokines (IL-1 and IL-6) and lung inflammation by Coronavirus-19 (COVI-19 or SARS-CoV-2): anti-inflammatory strategies. J Biol Regul Homeost Agents. 2020;34:2.

78. Runfeng L, Yunlong $H$, Jicheng $H$, Weiqi P, Qinhai M, Yongxia S, Chufang L, Jin Z, Zhenhua J, Haiming J, Kui Z, Shuxiang H, Jun D, Xiaobo L, Xiaotao H, Lin W, Nanshan Z, Zifeng Y. Lianhuaqingwen exerts anti-viral and antiinflammatory activity against novel coronavirus (SARS-CoV-2). Pharmacol Res. 2020;156:104761.

79. Ju B, Zhang Q, Ge X, Wang R, Yu J, Shan S, Zhou B, Song S, Tang X, Yu J, Ge J, Lan J, Yuan J, Wang H, Zhao J, Zhang S, Wang Y, Shi X, Liu L, Wang X, Zhang Z, Zhang L. Potent human neutralizing antibodies elicited by SARSCoV-2 infection. bioRxiv. 2020;2003(2021):990770

80. Arabi Y, Balkhy H, Hajeer AH, Bouchama A, Hayden FG, Al-Omari A, AlHameed FM, Taha Y, Shindo N, Whitehead J, Merson L, AlJohani S, Al-Khairy K, Carson G, Luke TC, Hensley L, Al-Dawood A, Al-Qahtani S, Modjarrad K, Sadat M, Rohde G, Leport C, Fowler R. Feasibility, safety, clinical, and laboratory effects of convalescent plasma therapy for patients with Middle East respiratory syndrome coronavirus infection: a study protocol. Springerplus. 2015:4:709.

81. Turner RB, Felton A, Kosak K, Kelsey DK, Meschievitz CK. Prevention of experimental coronavirus colds with intranasal alpha-2b interferon. J Infect Dis. 1986;154(3):443-7.

82. Loutfy MR, Blatt LM, Siminovitch KA, Ward S, Wolff B, Lho H, Pham DH, Deif H, LaMere EA, Chang M, Kain KC, Farcas GA, Ferguson P, Latchford M, Levy G, Dennis JW, Lai EK, Fish EN. Interferon alfacon-1 plus corticosteroids in severe acute respiratory syndrome: a preliminary study. JAMA. 2003;290(24): 3222-8.

83. Mustafa S, Balkhy H, Gabere MN. Current treatment options and the role of peptides as potential therapeutic components for Middle East respiratory syndrome (MERS): a review. J Infect Public Health. 2018;11(1):9-17.

84. Andersen KG, Rambaut A, Lipkin WI, Holmes EC, Garry RF. The proximal origin of SARS-CoV-2. Nat Med. 2020;26:450-2.

85. Muth D, Corman VM, Roth H, Binger T, Dijkman R, Gottula LT, Gloza-Rausch F, Balboni A, Battilani M, Rihtaric D, Toplak I, Ameneiros RS, Pfeifer A, Thiel V, Drexler JF, Muller MA, Drosten C. Attenuation of replication by a 29 nucleotide deletion in SARS-coronavirus acquired during the early stages of human-to-human transmission. Sci Rep. 2018;8(1):15177.

\section{Publisher's Note}

Springer Nature remains neutral with regard to jurisdictional claims in published maps and institutional affiliations.

Ready to submit your research? Choose BMC and benefit from:

- fast, convenient online submission

- thorough peer review by experienced researchers in your field

- rapid publication on acceptance

- support for research data, including large and complex data types

- gold Open Access which fosters wider collaboration and increased citations

- maximum visibility for your research: over $100 \mathrm{M}$ website views per year

At BMC, research is always in progress.

Learn more biomedcentral.com/submissions 